\title{
What are we to do with feral publishers?
}

David Harvie, Geoff Lightfoot, Simon Lilley and Kenneth Weir.

Centre for Philosophy and Political Economy

University of Leicester

\section{Acknowledgement}

We are grateful to Ben Wynne, of the University of Leicester Library, who suggested many of the references we draw on. 


\section{What are we to do with feral publishers?}

\section{International Studies in Egregious Behaviour?}

Informa plc. is a multinational with three main business areas: academic publishing (principally under the Taylor and Francis and Routledge imprints), commercial intelligence (Lloyds list, Datamonitor, etc.) and Events hosting. In 2010 the group reported a total turnover of $£ 1,226.5$ million, operating profit of $£ 164$ million and after tax profits of $£ 98.9$ million.

Over half of Informa's total annual operating profit was derived from academic publishing: f85.8 million. Looking in a little more detail, we discover that academic publishing produced a net profit margin for Informa of over 35 per cent compared to the 4 per cent profits derived from their 'events' division. A little more reading above the line here, along with comparison with other publishers' public accounts, suggests that journals provided gross profit margins of over 70 per cent. This seems to be a fairly healthy return in an economic climate in which the real return on seen-to-be-safe long term government debt is frequently negative. So, one would think, surely the executives of fine engines of the knowledge economy - such as Informa - would be more than happy with the level of profitabilty that they are garnering from publicly funded labour (see also Monbiot, 2011 and Beverungen et al, this volume).

Such a position fails to recognise just how feral some of our allies in the academic supply chain can be. For Informa formally moved abroad in 2009, ${ }^{1}$ upon which the company became a Jersey company domiciled in Zug, Switzerland. The canton of Zug has the lowest tax rates in Switzerland. ${ }^{2}$ Income tax 'works out at just 10 per cent on average'(Switzerland in the UK - Supplement to the International Swiss Review, 07/04/2010). 'Informa, who own the international shipping bible Lloyd's List, says the move has saved it a cool $f 12$ million a year.' (Switzerland in the UK - Supplement to the International Swiss Review, 07/04/2010).

Informa's accounts suggest that the move cost something in the region of $£ 4.3$ million, constituting a net 'saving' for the organisation of just shy of $£ 8$ million (but of course, still implying a total net loss to the UK treasury of something in the order of $£ 13$ million), with these $\mathrm{f} 4.3$ million in 'costs' seemingly largely taken up with the expenditure attendant upon redomiciling their senior executives. And along with these housing perks there are some

\footnotetext{
${ }^{1}$ Although the move had been discussed as early as 2006 (interview with company secretary John Burton by Abigail Townsend, The Lawyer, 18 March 2011).

${ }^{2}$ Corporate Tax rate in Zug, is approx. 19\%, but Peter Robinson of Forbes suggests deals can be cut with Swiss officials to negotiate rates down to around $10 \%$. However, uncertainty prevails over the exact tax rate as alternative estimates place the corporate rate between 15-16\% (http://www.forbes.com/2009/09/17/taxescorporations-business-globalization-opinions-peter-robinson.html, last consulted $30^{\text {th }}$ August 2011), and individual rates at $12.3 \%$ (http://www.fita.org/countries/ch.html?ma_rubrique=fiscalite, last consulted $30^{\text {th }}$ August 2011), suggesting a particular fluidity to rates in the canton.
} 
significant other benefits for our doughty stewards. The four senior executives who 'moved' to Zug as part of the deal will also have seen their personal tax liability slashed. Certainly the chief executive will have dodged a considerable sum of income tax each year, given the difference between the top 50 per cent rate in the UK and the headline 10 per cent rate in Zug. His Informa income, drawn from their annual statement, is detailed in Table 1, below (and converted into British Pounds). Were the standard rates of tax to have been applied to all his income (unlikely, of course, given the elliptical schemes by which many CEOs are rewarded), then the amount skipped would be considerably over half a million pounds a year.

Table 1: Informa CEO annual remuneration, 2010

\begin{tabular}{lrr}
\hline & Swiss francs & Pounds sterling \\
\hline Salary & $1,190,000$ & 810,390 \\
Benefits & 270,000 & 183,870 \\
Bonus & $1,285,000$ & 875,085 \\
Deferred Bonus & 94,538 & 64,380 \\
Long Term Incentive Plan & 155,229 & 105,711 \\
\hline Total & $\mathbf{2 , 9 9 4 , 7 6 7}$ & $\mathbf{2 , 0 3 9 , 4 3 6}$ \\
\hline
\end{tabular}

Business as usual? Well perhaps. But maybe not so usual as to merit no commentary. In a context in which groups such as UK Uncut are keen to highlight alternatives to the There Is No Alternative mantra of ever increasing austerity - not to mention an impending fees regime in which potential students are being invited to pay three times the amount for exactly the same product - it does seem to us to be little bit beyond even the ordinary pale.

Whilst Informa's tax avoidance does render it as something of a moral outrider here, it is far from alone in scalping the public purse for private profit in pursuit of disinterested truth. As Table 2 makes clear, academic publishing is, and is increasingly, a veritable licence to print money.

Table 2: Journal publishing profitability

\begin{tabular}{|c|c|c|c|c|c|}
\hline & $\begin{array}{l}\text { Journal/publishing } \\
\text { turnover }\end{array}$ & $\begin{array}{l}\text { Operating } \\
\text { Profit }\end{array}$ & $\begin{array}{l}\text { Operating } \\
\text { Profit \% }\end{array}$ & $\begin{array}{l}\text { Gross } \\
\text { profit }\end{array}$ & $\begin{array}{l}\text { Gross } \\
\text { profit } \\
\%\end{array}$ \\
\hline \multicolumn{6}{|l|}{ The 'big 3' } \\
\hline Elsevier & $€ 2,026,000,000$ & $€ 647,000,000$ & 31.9 & $\begin{array}{r}\text { Not } \\
\text { available }\end{array}$ & $\begin{array}{r}\text { Not } \\
\text { available }\end{array}$ \\
\hline $\begin{array}{l}\text { Springer } \\
\text { (STM } \\
\text { division) }\end{array}$ & $€ 655,000,000$ & $\begin{array}{r}€ 238,000,000 \\
(\text { EBITDA) }\end{array}$ & $\begin{array}{r}\text { Not } \\
\text { available }\end{array}$ & $\begin{array}{r}\text { Not } \\
\text { available }\end{array}$ & $\begin{array}{r}\text { Not } \\
\text { available }\end{array}$ \\
\hline $\begin{array}{l}\text { John Wiley } \\
\text { (STMS }\end{array}$ & $\$ 986,683,000$ & $\$ 405,244,000$ & 41.1 & $\begin{array}{r}\text { Not } \\
\text { available }\end{array}$ & $\begin{array}{r}\text { Not } \\
\text { available }\end{array}$ \\
\hline
\end{tabular}


division)

\begin{tabular}{lrrrrr}
\hline $\begin{array}{l}\text { Selected other publishers } \\
\text { Informa } \\
\text { (journals \& }\end{array}$ & $£ 294,400,000$ & $£ 109,300,000$ & 29.1 & $\begin{array}{r}\text { Not } \\
\text { available }\end{array}$ & $\begin{array}{r}\text { Not } \\
\text { available }\end{array}$ \\
$\begin{array}{l}\text { books) } \\
\text { Sage (UK) }\end{array}$ & & & & & \\
Emerald & $£ 77,269,000$ & $£ 14,365,000$ & 18.6 & $47,929,000$ & 62.0 \\
\hline
\end{tabular}

All figures taken from most recent publicly available financial statements

The net profits secured by all of these major publishers are, to put it mildly, substantial. And it's worth noting that, following what appears to be best practice in corporate governance, two of the 'big three' are headquartered in notorious low-tax havens (although the taxexempt status of holding companies in Luxembourg was recently revoked under pressure from the EU). ${ }^{3}$

The figures in Table 2 for the 'big three' (Elsevier, Springer and John Wiley) concentrate on operating profit as these are the figures most readily available for academic publishing. However, these can be misleading as to the scale of profits enjoyed-operating profit includes a range of expenses that can be apportioned in different ways across the different units of complex organizations. Gross profit - the profit realised after production and distribution - might give a better picture but where the big three publish gross profit figures, they include profits from a range of other activities. To get an indication of the kind of profits available from journal publishing, we can look at some of the smaller publishers, particularly those registered in the UK, where disclosure requirements for limited companies are relatively high.

Sage, the publisher of this journal, shows a gross profit across both books and journals of over 60 per cent. A smaller publisher, Emerald, which concentrates more on journals, is able to register a gross profit of over 75 per cent. Given that the perceived quality of the journal enables publishers to demand higher prices, and Emerald has relatively few highly ranked journals, it is likely that gross profits for journals for major publishers are even higher than the 77 per cent recorded by Emerald.

We are aware of only two other industries where these sorts of return are on offer: that in illegal drugs and the delivery of university-level business education. We have, of course, limited experience of the former; rather more of the latter. However, we would note that the scalping associated with business education must itself be viewed in the context of restricted public financial support confronting a touching desire within the sector for maintenance of a university worth of the name.

\section{Research into publishing}

Journal publishing is increasingly researched, providing a rich seam of material that finds its

\footnotetext{
${ }^{3}$ Springer in Luxembourg, John Wiley in Delaware.
} 
way into academic journals themselves, and beyond. A few minutes' exploration on the EBSCO database reveals exponential growth in this area over the past two decades or more: between 1991 and 1995 fewer than 100 peer-reviewed articles were published with 'scholarly publishing' or 'journal publishing' as subject terms. ${ }^{4}$ Over the next five years, more than 300 such pieces were published; in the period 2001-05, almost 700 articles on publishing were published; and for 2006-10, more than 2,000. Of course, not all these articles are directly relevant to the questions we are interested in here, but a good number of them are. This perhaps reflects an increasing concern, as here, in the rapidly appreciating costs of academic journals.

As Loughborough University's Library and Information Statistics Unit (LISU; a unit that has been collecting data on library expenditure since 1987) reports,

Serial subscriptions spend by UK higher education institutions (of which peer-reviewed scholarly journals are a sub-set of unknown size) totalled f94.5 million in 2003-2004 [and which we estimate, from LISU's Lampost archive, to be over $£ 130$ million in 2008/9]. The number of current serial subscriptions has doubled in higher education institutions over the past ten years. Much of this growth in volume is thought to be attributable to 'bundled' or packaged deals offered by publishers.

Published sources estimate publisher revenues of circa $\$ 5$ billion for English-language journals in scientific, medical and technical disciplines in 2004. It is likely that this is a significant under-estimate of the total peer-reviewed journal market (it excludes nonEnglish language journals, journals in disciplines outside of STM such as social sciences, the arts and humanities and is necessarily based on 'best estimates' of journal revenues derived from figures in published accounts). (Oppenheim/LISU 2006: 5-6)

The average journal price, from a UK publisher in 2009 for journals in the area of social sciences, was $£ 510.66$. (LISU http://www.lboro.ac.uk/departments/ls/lisu/lampost10/exp10.html last consulted 30 August 2011). As an example, the institutional subscription price of Organization is provisionally set at $£ 891.25$, at least for the University of Leicester. It is apparent that although not every HE institution in the UK that teaches business and management subscribes to it, the vast majority do. This suggests that the revenue from institutional subscribers to Organization in the UK alone will be in the region of $£ 90,000$. For a more expensive journal, such as Routledge's International Journal of Human Resource Management, we are probably looking at UK institutional revenues in the order of £200,000.

More generally, Dewatripont et al. (2007) explore pricing in 2003 of 2,630 journals across 22

\footnotetext{
${ }^{4}$ All EBSCO databases.
} 
fields of social and natural sciences. They distinguish publishers into three types: for-profit; not-for-profit (learned societies, university presses, etc.); and for-profit publishers distributing on behalf of learned societies. Using econometric analysis they find that a number of factors affect journal pricing. First, and most importantly, for-profit publishers charge roughly four times more than not-for-profit publishers, with for-profits publishing on behalf of scholarly societies charging twice as much. (This confirms Bergstrom and Bergstrom's (2004) finding that a journal page published by a for-profit is between three and five times more expensive than one published by a not-for-profit.)

Dewatripont et al. also find that more highly-cited journals are more expensive, with this effect being more pronounced for journals published by for-profits. They suggest that citation-counts are "an indication of "quality" and of high value to the reader. This can turn a profit-maximizing publisher to raise its price because the willingness to pay of readers increase' (sic., pp. 405-7). Though, as they point out, one would expect more highly cited journals to have a wider circulation and therefore lower average production costs.

They find that journal subscription prices increase with number of articles, with a 10 per cent increase in the number of articles increasing price by $3-5 \%$, and that English-language journals are 20-60 per cent more expensive than journals published in other languages. This is not always the case: one of our sources alleges that the then editor of this journal was approached by his Sage contact, who proposed increasing the number of issues printed each year. When the editor expressed doubts about the work involved in managing the extra content, the Sage representative confessed that there was no need to include more papers since the same number of accepted submissions could be spread more thinly across more issues. However, the additional issues could be used to justify an increase in the subscription price.

Finally, investigating the large differences in journal pricing across scientific fields, with average prices varying by a factor of up to 6, Dewatripont et al. discover these are correlated with publishers' market power: the higher the concentration ratio in a particular field, the higher the average journal price.

Many of these concerns were shared by the Office of Fair Trading, which concluded in 2002 that 'the market [in journal publishing] may not be working well' (OFT 2002). In particular, the OFT registered concerns over price increases above inflation; the disparity in prices between commercial and non-commercial scientific, technical and medical (STM) journals; the profitability of commercial STM publishing, which it estimated to be 10-15 per cent above other forms of commercial journal publishing; and the development of terms for electronic access and 'bundling', which it feared would hinder others from entering the market. The OFT, however, also optimistically identified a number of ways in which 'emerging market forces may in practice address the problems, without the need for regulatory intervention'. A decade later, the benefits of such a light touch may well be being 
felt in Switzerland, Luxembourg and Delaware.

\section{Deal or No Deal?}

The practices of publishers impact on higher education in two ways. First, actions like those of Informa deprive the UK Treasury of tax revenues and thus contribute to the 'fiscal crisis of the state' which has led to the squeeze on public funding for universities. Second, publishers' pricing policies have a direct and immediate impact on university libraries, and therefore on academics' and students' ability to access information and knowledge knowledge that they, collectively, have produced.

Over the past decade, university libraries' real spending has increased by 31 per cent. But with universities and colleges increasing their expenditure by around 60 per cent over this same period, libraries' share of this spending has fallen from 3.4 per cent to 2.5 per cent, whilst library spending per student has only risen by 8 per cent, reaching $£ 416$ per student per year in 2009 (in 2011 prices). ${ }^{5}$

Libraries' single biggest item of expenditure is on staffing, which takes roughly half of library budgets. After that is 'information provision' - spending on books and periodicals, both printed and electronic - which accounts for a little over a third of total spending. This figure has remained roughly constant over the decade, but the balance between books and serials (periodicals) has shifted significantly.

Since 1999, spending on books has fallen by almost a fifth in real terms, and from almost 12 per cent of libraries' total spending to just over 8 per cent. Expenditure on serials, on the other hand, has increased sharply: from just under $£ 70$ million to over $£ 130$ million. In real terms this represents an increase of 63 per cent; journals' share of total library spending rose from 16 per cent to almost 20 per cent. $^{6}$

According to other respected observers of the 'information provision' industry,

These changes are the result in large part of the Big Deals introduced by many publishers of scholarly journals, providing access to a wide range of journals in electronic form at a discounted price. Such deals have dramatically increased the number of titles available in individual universities, and have changed fundamentally the expectations of staff and students. They also involve, however, a contract of several years' duration, with an annual price increase. [Our own librarian suggests well in excess of RPI, 7 per cent per annum being typical.] Librarians thus find that

\footnotetext{
${ }^{5}$ All data is taken from RIN/SCONUL (2010).

${ }^{6}$ Looking just at expenditure on serials, there has been a big shift away from print journals and towards electronic journals. Between 2001 and 2009 print-only journals' share of serials expenditure has fallen from $66 \%$ to $22 \%$, while electronic-only journal spending now accounts for almost half, up from $10 \%$; spending on subscriptions that provide both printed journals and electronic access has risen slightly, from $25 \%$ of serials expenditure to $29 \%$.
} 
increasing proportions of their budgets are tied up in big deals, with an inevitable impact upon other budgets, including those earmarked for buying books.

(RIN/SCONUL 2010: 14)

Although the Research Information Network (RIN) and the Society of College, National and University Libraries (SCONUL) are right to note the impact on the book budget, perhaps more serious is the impact on alternative means of publishing academic journals and disseminating scholarly research.

In 2004, there was a major parliamentary investigation into the operation of the journals market. The resulting report (House of Commons 2003-04) was critical of the pricing policies of major commercial publishers and concluded that 'a Government strategy is urgently needed'. As an immediate step the report recommended 'that all UK higher education institutions establish institutional repositories on which their published output can be stored and from which it can be read, free of charge, online. It also recommended that Research Councils and other Government funders mandate their funded researchers to deposit a copy of all of their articles in this way'. The report's summary continued, 'Institutional repositories will help to improve access to journals but a more radical solution may be required in the long term. Early indications suggest that the author-pays publishing model could be viable. We remain unconvinced by many of the arguments mounted against it.' This report received a cool reception from the government at the time; and although research archives are now common, their influence in the research-audit culture remains marginal. A key reason for this is no doubt the insistence of established journals upon appropriately-paginated referencing of the versions of sources that can be found only in restricted access, rather than to their open-access doppelgängers.

Given these limitations upon the capacity of open repositories to fracture the status quo and academics' and librarians' widespread dissatisfaction with the still-dominant commercial model and its pricing structure, why aren't more journals published by scholarly societies (scholarly/learned societies publish 30 per cent of all journal articles, with university presses publishing a further 4 per cent (Oppenheim/LISU (2006 p. 41, Table 1.15))? ${ }^{7}$ Why don't more journal editors follow example of Topology's editorial board, which in 2006 resigned en masse in protest at Elsevier's pricing of the journal, and launched instead Journal of Topology, owned by the London Mathematical Society? ${ }^{8}$ Why aren't more journals open-access (around 10 per cent of peer-reviewed journals are currently openaccess (Oppenheim/LISU 2006 p. 20) and a study by Björk et al. (2010) which searched for 1837 randomly-selected articles, discovered that ' $8.5 \%$ were freely available at the publishers' sites. ... [A]n additional $11.9 \%$ free manuscript versions could be found using search engines, making the overall OA percentage $20.4 \%$ ')?

\footnotetext{
${ }^{7}$ Commercial publishers, including commercial publishers publishing on behalf of societies, publish $64 \%$.

${ }^{8}$ See Jackson (2007)
} 
Part of the answer lies in the big deals outlined above, which leave individual journals as the only possible candidates for cuts in library budgets. Another part may reside in the apathy of academics and the gap between their traditional skill set and that of the publicist/publisher, together with the additional time and costs that must be borne should editors choose a route such as that developed by ephemera. But that is probably not the whole story and the venality of extant providers goes some way to filling the final gap. We explore further anecdotal accounts of publishers' behaviour in the face of challenges to their hegemony to reveal just how parlous our state of things is.

\section{Challenging the Indefensible}

One of us used to be the editor of a Taylor and Francis journal. The journal has been published for over 15 years (not all of them with Taylor and Francis) and has recently been accepted for Thomson ISI listing, a virtue that almost inevitably enhances both impact factor and position of various research ranking lists. On discovering the egregious tax avoiding practices of Taylor and Francis's parent, Informa, the editors decided to explore alternative routes to market. Our initial approach was to another publisher, one which to be sure is still making the sorts of supranormal profits seen throughout the sector but one which has at least thus far not been tempted to take a tax sabbatical. One of the reasons for doing this was in an attempt to maintain the valuable ISI listing, for more radical action such as that engaged in by our topologists would have meant starting again from scratch in terms of securing this kitemark. The other reason was to try to ascertain the 'value' of the outlet to the industry by encouraging the current publishers to name their price in the transfer negotiations. This move itself was prompted by prior frustration with the woefully limited editorial support available from the journal's coffers, something in the order of $£ 2,000$ per year for a part-time editorial assistant. Previous attempts to get this contribution uplifted had been confronted with, in the light of our account above, laughable stories of the tight economics of the journal publishing business, with the only change we could eventually engineer in level of support being attendant upon agreement to increase the page budget and number of issues and hence the subscriptions commandable. However, it quickly became clear to us that journals are a bit like Premiership footballers in terms of their transferability. The publisher who we had interested in taking the journal on reported that they could not 'legally' make an approach to the current publisher to begin negotiations on this because such was only acceptable if and when the current publisher had clearly communicated a desire to sell in the absence of prior approach. And, as we have been reminded only too often as editors, we have no intellectual property rights whatsoever in the organs we realise through our unpaid labour. Such resides in its entirety with the publisher and the publisher alone, a situation that thankfully does not beset those outlets whose delivery to market is orchestrated by learned societies.

Our question, which we set out in the title to this paper, was what are we to do with feral publishers? The Cats Protection charity, in attempting to control the feline population, has a 
policy of capturing feral cats, neutering them, and then re-releasing them into the wild. Would that we could do the same with our publishers. Instead, it is the academic community - academics, students, libraries - that has been captured and seemingly neutered, leaving publishers to run amok.

At a time when the public sector is being forced to cut savagely, pruning jobs and services, the increasing profits being gouged from shrinking academic budgets by the parasitical publishing industry are hard to stomach. But even within that scabrous community, Informa appears to have set a new marker in displaying its contempt, seeking to minimize its contribution to the sector that provides the majority of its profits. ${ }^{9}$ We therefore suggest that the only reasonable response is to demand that Informa repay the tax that it has looted from the system. If it fails to do so, then it becomes hard to see how or why we should respect their intellectual property. At one level, this merely means refusing to use Routledge and Taylor and Francis journals - either as an outlet for our academic labour or as a resource in teaching and scholarship. More basely, we should perhaps consider offering support, even if only verbal, to those who would more freely distribute their copyrighted material.

Informa's tax-dodging actions are perhaps the most visibly callous but that does not excuse other publishers, including Sage. We call upon the editors of Organization to press Sage to lower the subscription price to a more acceptable level - such as the $£ 123$ charged for the AMJ or the $£ 182$ for ASQ. When that approach fails, as past experiences of discussions with commercial publishers on the issue of price indicate it inevitably will, we suggest that the editors, writers and readers of Organization follow the example set by Topology in leaving the journal en masse to set up, submit to and subscribe to an identical journal, ideally through a learned society, that charges a more acceptable fee. This is not only more appropriate for a journal that wears a critical badge, however lightly, but also provides renaming opportunities that would delight a hairdresser.

\section{References}

Bergstrom, Carl and Bergstrom, Ted (2004) 'The Costs and Benefits of Library Site Licenses to Academic Journals', Proceedings of the National Academy of Sciences of the USA, 101, 897-902.

Björk, Bo-Christer; Welling, Patrik; Laakso, Mikael; Majlender, Peter; Hedlund, Turid; and Guðnaso, Guðni (2010), 'Open Access to the Scientific Journal Literature: Situation 2009', PLOS ONE. Available at

\footnotetext{
${ }^{9}$ Informa apparently believes in 'Giving back to the communities in which it operates' (AR, p49). Not in the form of tax, obviously. Nor much elsewhere: $£ 30,700$ in donations, $£ 26,321$ in matched funding. Less than 0.005 per cent of turnover.
} 
http://www.plosone.org/article/info\%3Adoi\%2F10.1371\%2Fjournal.pone.0011273; last accessed 19.08.2011.

Dewatripont, Mathias; Ginsburgh, Victor; Legros, Patrick; and Walckiers, Alexis (2007)

'Pricing of scientific journals and market power', Journal of the European Economic Association, Vol. 5 Issue 2/3, pp. 400-410.

Houghton, John; Rasmussen, Bruce; Sheehan, Peter; Oppenheim, Charles; Morris, Anne; Creaser, Claire; Greenwood, Helen; Summers, Mark; and Gourley, Adrian (2009) Economic Implications of Alternative Scholarly Publishing Models: Exploring the Costs and Benefits. A report to the Joint Information Systems Committee, www.jisc.ac.uk. Available at http://www.jisc.ac.uk/media/documents/publications/rpteconomicoapublishing.pdf; last accessed 19.08.2011.

House of Commons (2003-04) Science and Technology: Tenth Report, 7 July. Available at http://www.publications.parliament.uk/pa/cm200304/cmselect/cmsctech/399/39902.htm; last accessed 19.08.2011.

Jackson, Allyn (2007) 'Jumping ship: Topology board resigns', Notices of the AMS, May: pp. 637-639. Available at http://www.ams.org/notices/200705/comm-toped-web.pdf; last accessed 19.08.2011.

Monbiot, George (2011) 'Academic publishers make Murdoch look like a socialist', The Guardian, 30 August. Available at

http://www.guardian.co.uk/commentisfree/2011/aug/29/academic-publishers-murdochsocialist; last accessed 31.08.2011.

Office of Fair Trading (2002) The market for scientific, technical and medical journals. A statement by the OFT, September. Available at

http://www.oft.gov.uk/shared oft/reports/media/oft396.pdf; last access 19.08.2011.

Oppenheim, Charles and LISU (2006) UK scholarly journals: 2006 baseline report. An evidence-based analysis of data concerning scholarly journal, Final Report, 12 September (London: Research Information Network, Research Councils UK and the Department of Trade \& Industry). Available at http://www.rin.ac.uk/our-work/communicating-anddisseminating-research/uk-scholarly-journals-2006-baseline-report; last accessed 16.08.2011.

Research Information Network and Society of College, National and University Libraries (2010) Trends in the finances of UK higher education libraries: 1999-2009, September (London: RIN and SCONUL). Available at http://www.rin.ac.uk/system/files/attachments/library trends report_screen.pdf; last accessed 16.08.2011. 